\title{
Analysis of the biological efficiency and quality factors of mushrooms of the genus Pleurotus (Fr.) P.Kumm as a model of effective cultivation of lignicolous fungi with high functional value
}

\author{
I. I. Bandura ${ }^{1 *}$, A. S. Kulik ${ }^{1}$, N. A. Bisko ${ }^{2}$, O. V. Khareba ${ }^{3}$, 0. M. Tsyz ${ }^{4}$, V. V. Khareba ${ }^{3}$ \\ ${ }^{1}$ Dmytro Motornyi Tavria State Agrotechnological University, 18 B. Khmelnytskyi Ave, Melitopol, Zaporizhzhia region, 72312, \\ Ukraine, ${ }^{*}$-mail: irabandura@gmail.com \\ ${ }^{2}$ M. G. Kholodny Institute of Botany, National Academy of Sciences of Ukraine, 2 Tereshchenkivska St., Kyiv, 01004, Ukraine \\ ${ }^{3}$ National Academy of Agrarian Sciences of Ukraine, 9 Mykhailo Omelianovych-Pavlenko St., Kyiv, 01010, Ukraine \\ ${ }^{4}$ National University of Life and Environmental Sciences of Ukraine, 15 Heroiv Oborony St., Kyiv, 03041, Ukraine
}

\begin{abstract}
Purpose. Morphological and organoleptic evaluation of oyster mushroom strains for selection of highly productive cultivars assortment with valuable consumer properties for winter and summer cultivation and suitability for sale in fresh or processed form were investigated. Methods. The scheme of the experiment included six strains of oyster mushrooms belonging to two species: Pleurotus ostreatus (5 strains: 2301, Z, 2316, 2456, 431) and P. pulmonarius (2314). Laboratory, laboratory-industrial and statistical methods are used. Results. The dynamics of agrochemical parameters of substrates obtained by the method of aerobic fermentation in the high layer proved their optimality according to the main criteria and compliance to regulatory documentation. The biological efficiency of the strains was in the range of $40-78.9 \%$. The highest weight of clusters was found in the "summer" strain $431(430.7 \mathrm{~g})$. The highest weight of the fruiting body was determined for the strain $2301(15.2 \mathrm{~g})$, the lowest - for the $2456(3.3 \mathrm{~g})$. Conclusions. The values of biological efficiency of strains was determined. The highest average values for the first flush of fruiting had strains $2316(78.9 \%)$ from the "winter" group (A) and 431 (78.4\%) from the "summer" group (B). According to the results of statistical analysis, significant differences were revealed between the studied strains in the main morphological indicators of clusters. It was found that the mass of clusters of «winter» cultivars is much less dependent on the strain type (220.8-273.4 g) than that of «summer» cultivars $(83.4-430.7 \mathrm{~g})$. The index of the asymmetry coefficient of the cluster, which can be useful for calculating the required container sizes was proposed. It was determined that the morphological features of fruiting bodies had significant differences in all studied parameters. In particular, the A group strains differed in size and weight. It was proposed the index of weight loss of the crop coefficient, which shows the ratio between the cap and stipe of the fruiting body and make it possible to predict the amount of mushroom raw material that will be sold in the form of caps, and the amount of raw material that can be processed into minced mushroom, powder and others. The best coefficient was obtained for the fruiting bodies of strain 2314 (0.87), and the worst - for $2456(0.59)$, which, accordingly, is not recommended for sale by individual fruiting bodies. It was found that the fruiting bodies of high-yielding strains 2316 and 431 had a number of organoleptic defects.
\end{abstract}

Keywords: oyster mushroom; strains; biological efficiency; cluster; fruiting body; organoleptic evaluation.

\section{Introduction}

The expansion of the range of cultivated mushrooms has become a general trend in the modern world. At the 8th International Conference on Mushroom Biology and Mushroom Pro-

\footnotetext{
Iryna Bandura

https://orcid.org/0000-0001-7835-3293

Alina Kulik

https://orcid.org/0000-0001-5403-3084

Nina Bisko

https://orcid.org/0000-0003-1894-0896

Olena Khareba

https://orcid.org/0000-0002-6763-1988

Oleksandr Tsyz

https://orcid.org/0000-0001-7174-7011

Volodymyr Khareba

https://orcid.org/0000-0001-9947-2689
}

ducts (India, 2014), Professor Daniel J. Royse noted that in the United States mushroom consumption has quadrupled over the past 15 years and continues to grow [1]. American scientists, analyzing the factors affecting the consumption of mushrooms in the United States, note an increase in demand in the main age group of buyers - people aged 20 to 39 years [2]. Analysis of mushroom cultivation in China, where the share of the world «mushroom» market exceeds $30 \%$, confirms the increase in consumption of exotic mushrooms from $6 \mathrm{~kg} /$ year in 2003 to $10 \mathrm{~kg}$ in 2008 (more than 66\%). At the same time, the production of champignons in this country decreased, while oyster mushrooms over 5 years increased 1.4 times, shiitake 1.7 times, and enoki -2.12 times [3].

The International Marketing Group (IMG), analyzing the state of the Ukrainian mush- 
room market, notes that the demand for mushroom products is due to their taste characteristics and high functional properties, in particular, their high protein content. Moreover, the price of mushrooms is not a limiting factor, since they are most often bought by people whose income is above average.

The study of the International Independent Institute for Investment Policy Analysis (IIIIPA) focuses on the trend towards the separation of production areas in the mushroom business: large specialized companies engaged in the production of compost and substrates unite around themselves farms for growing mushrooms, accept ready-made products for sale, accumulate it in sufficient quantity to ensure timely stable supply of fresh mushrooms to retail chains. In Ukraine, this principle is implemented in such companies as «Ecohryb» LLC and SPC (Dobrovelychkivka, Kirovohrad region), «Druidy» LLC (Kryvyi Rig, Dnipropetrovsk region), «Ukrainian Mushroom Company» LLC (St. Kamianske, Dnipropetrovsk region), «Doctor Mushroom» LLC SPC (Melitopil, Zaporizhzhia region), which in general terms determined the work of $80 \%$ of producers of oyster mushrooms and other exotic mushrooms in 2019. According to the reporting data from «Doctor Mushroom» company management, these enterprises produced more than 5 million $\mathrm{kg}$ of substrate for the year, which, according to an average yield of $20 \%$, provided at least 1 million $\mathrm{kg}$ of fresh oyster mushrooms. So, in just 2019 in Ukraine, 1 million 250 thousand $\mathrm{kg}$ of oyster mushrooms were produced and sold (with considering the lack of export), which in terms of per capita consumption at the age of 16 to 59 was only $50 \mathrm{~g}$ (according to the State Statistics Service of Ukraine this category of the population in January 2019 amounted to 25 million 294 thousand people).

Assessment of the state of domestic manufacturers scientific and technical potential, as well as the presence of a solid scientific base founded on the works of a number of Ukrainian researchers, such as I. A. Dudka, A. S. Bukhalo, E. F. Solomko, N. A. Bisko, A. V. Babaiants and many others, makes it possible to talk about the prospects for expanding the range and strengthening the market of exotic mushrooms in Ukraine. However, to realize this potential, it is necessary to conduct a number of new studies and in-depth analysis of previous ones. To increase consumer interest and actively attract buyers, in addition to the issues of preserving the nutritional value of mushroom products during processing, morphological and organoleptic characteristics should be investigated.
The purpose of the research is to conduct a morphological and organoleptic assessment of oyster mushroom strains for the selection of an assortment of highly productive and valuable in terms of consumer properties cultivars for winter and summer cultivation and suitability for sale in fresh or processed form.

\section{Materials and methods}

We analyzed the data obtained as a result of laboratory and industrial research from 2011 till 2019, carried out in the laboratory of the Dmytro Motornyi Tavria State Agrotechnological University (TSATU) and at the enterprises of a private entrepreneur Sevastianovych V. M. and «Doctor Mushroom» LLC SPC (Melitopil, Zaporizhzhia region).

Two groups of strains were studied: with lowtemperature $\left(12-16{ }^{\circ} \mathrm{C}-\right.$ group A) and hightemperature (19-24 ${ }^{\circ} \mathrm{C}$ - group B) fruiting optimum. The first group includes strains 2301, $\mathrm{Z}, 2316$, the second $-2314,2456$, and 431 [4, 5]. The culture of the strains was obtained from the IBK mushroom collection of the M. G. Kholodny Institute of Botany NAS of Ukraine.

The substrate for oyster mushrooms growing was prepared by the method of aerobic fermentation in a high layer (AFHL) [6, 7]. Raw plant material was used in the following proportions: chopped barley straw $(40-60 \mathrm{~mm})-30-50 \%$; sunflower husk $-45-55 \%$; alfalfa hay $-4-9 \%$; corn flour $-1 \%$. The formulation was changed on the basis of biochemical analysis of raw material, whose composition depended on the agrotechnological conditions of their production. The main factor for adjusting the substrate formula was the total nitrogen indicator, which was calculated at a level of $0.8 \%$ (by dry weight).

The quality of the substrate was evaluated by the following criteria: humidity, $\mathrm{pH}$, content of total nitrogen and mineral elements, the ratio of carbon to nitrogen determined by standard methods in the laboratory of TSATU [8]

The substrate bags were placed in the growing chambers according to the single-zone cultivation systipe on shelves or suspension with an average chamber load from 50 to $120 \mathrm{~kg} / \mathrm{m}$ [9]. The bags were perforated with cuts of $80 \pm$ $30 \mathrm{~mm}$ so that the distance between them was 100-150 $\mathrm{mm}$. The total perforation surface did not exceed $1.5 \%$ of the bag surface.

The substrate was incubated at an average temperature of $15 \pm 5{ }^{\circ} \mathrm{C}$ in a cultivation chamber, depending on the strain cultural characteristics and a season. Complete colonization of substrates was recorded on the 8th \pm 2 day. The microclimate parameters for the initiation of fruiting began to change on the 10th day of 
incubation in the summer period (maybe «season» will be better?) and on the 16 th \pm 2 day in the autumn-spring period.

To determine the biological efficiency, the total weight of fruiting bodies (FB) from one substrate bag (sample of 50 bags for each strain) was calculated. Biological efficiency (BE) was determined only for the first fruiting flush by the formula:

$$
B E=\frac{\text { Weight of fresh mushrooms }}{\text { Dry weight of substrate }} \times 100 \%
$$

The number of fruiting bodies, weight and sizes were calculated for each cluster, collected from each block of the substrate during the first fruiting flush. The coefficient of asymmetry of the cluster was calculated as ratio of its width to height.

For morphological analysis of individual fruiting bodies, their mass and mass of the cut off cap, width and height of the cap, length of the stipe and its diameter were determined. The area of the cap was calculated using the formula for calculating the area of an ellipse (considering the asymmetry of the cap):

$$
S=\varpi \times a \times b
$$

where $\mathrm{S}$ is the area of the ellipse; a - the length of the semi-major axis of the ellipse (1/2 the width of the cap) $b$ - the length of the semi-minor axis of the ellipse ( $1 / 2$ the height of the cap).

The cap asymmetry coefficients (AC) were calculated in relation to the width of the cap to the height. The calculation of the weight loss coefficient (WLC) was added as the ratio of the mass of an individual cap to the weight of the whole fruiting body to be able to determine the decrease in the mass of mushrooms, which should be sold only in the form of separate caps (according to the modern requirements of the European market).

The variability of indicators was calculated with a sample of $n=100$ for both clusters and fruiting bodies.

The data were statistically processed using the Microsoft Office Excel 2016 package and the built-in QI Macros 2020 complex.

\section{Results and discussion}

According to the results of the statistical analysis of the obtained data, no significant differences were found in the quality of substrates manufactured at different enterprises by the AFHL method, which allows us to speak about the stability and efficiency of this pro- cessing of raw materials. The physicochemical parameters of the studied substrates met the requirements of the national regulatory documentation (GOST 7316:2013. Substrate mycelium of edible mushrooms. Specifications [10]) (Table 1).

Dynamics of substrate indicators obtained by the AFHL method (2014-2019)

\begin{tabular}{|c|c|c|c|c|c|}
\hline Year & $\begin{array}{c}\text { Moister } \\
\text { content, } \\
\%\end{array}$ & $\mathrm{pH}$ & $\begin{array}{c}\text { Total } \\
\text { nitrogen, } \% \\
\text { d.w. }\end{array}$ & $\begin{array}{c}\text { Ash, \% } \\
\text { d.w. }\end{array}$ & $\begin{array}{c}\mathrm{C} / \mathrm{N} \\
\text { ratio }\end{array}$ \\
\hline 2014 & $73.4 \pm 0.5$ & $7.10 \pm 0.2$ & $0.90 \pm 0.1$ & $5.63 \pm 0.3$ & $57 \pm 8.7$ \\
2015 & $74.0 \pm 0.9$ & $6.95 \pm 0.1$ & $0.87 \pm 0.04$ & $6.84 \pm 0.7$ & $57 \pm 2.8$ \\
2016 & $73.0 \pm 1.4$ & $7.41 \pm 0.4$ & $0.54 \pm 0.06$ & $9.41 \pm 1.1$ & $98 \pm 18.1$ \\
2017 & $74.2 \pm 1.4$ & $7.61 \pm 0.4$ & $0.59 \pm 0.05$ & $7.65 \pm 0.6$ & $85 \pm 6.9$ \\
2018 & $70.6 \pm 1.3$ & $7.10 \pm 0.4$ & $0.86 \pm 0.1$ & $6.17 \pm 0.4$ & $65 \pm 9.9$ \\
2019 & $72.1 \pm 1.3$ & $7.69 \pm 0.4$ & $0.89 \pm 0.2$ & $7.57 \pm 0.98$ & $69 \pm 21.5$ \\
\hline
\end{tabular}

At the same time, changes in the content of total nitrogen and ash elements in the substrates obtained in different years were revealed. Since carbon to nitrogen ratio is a calculated unit, the parameters of this indicator changed accordingly [11]. Certain dynamics requires further research, since it is possible to adjust the amount of nutrients in the raw material by changes in the substrate formulas: the addition of legumes hay, grain scraps, etc. [12-14].

As a result of the statistical analysis of biological efficiency, significant differences were recorded among the studied strains $(p<0.01)$ (Fig. 1).

Strains 2316 (A) and 431 (B) in the first flush of fruiting used the substrate with $78 \%$ efficiency, 1.5-2 times higher than those of other cultivars. The productivity of strains Z, 2314 and 2456 was low and did not differ significantly. It should be noted that the mass of the first flush of fruiting is indicative for the economic justification of mushroom production. However, for strains with a short technological cycle, for example, 2314 (the collection of the first flush took place on the 13 day from inoculation), the following flushes should also be taken into account, which can significantly increase BE.

In general, according to the results of comparing the average (U-test), the studied groups did not have significant differences, which allow us to speak about the expediency of «summer» cultivation. Changing the strains will make it possible to obtain crops throughout the year without additional economic costs for cooling or heating the cultivation premises.

According to the results of statistical analysis, significant differences between the mor- 


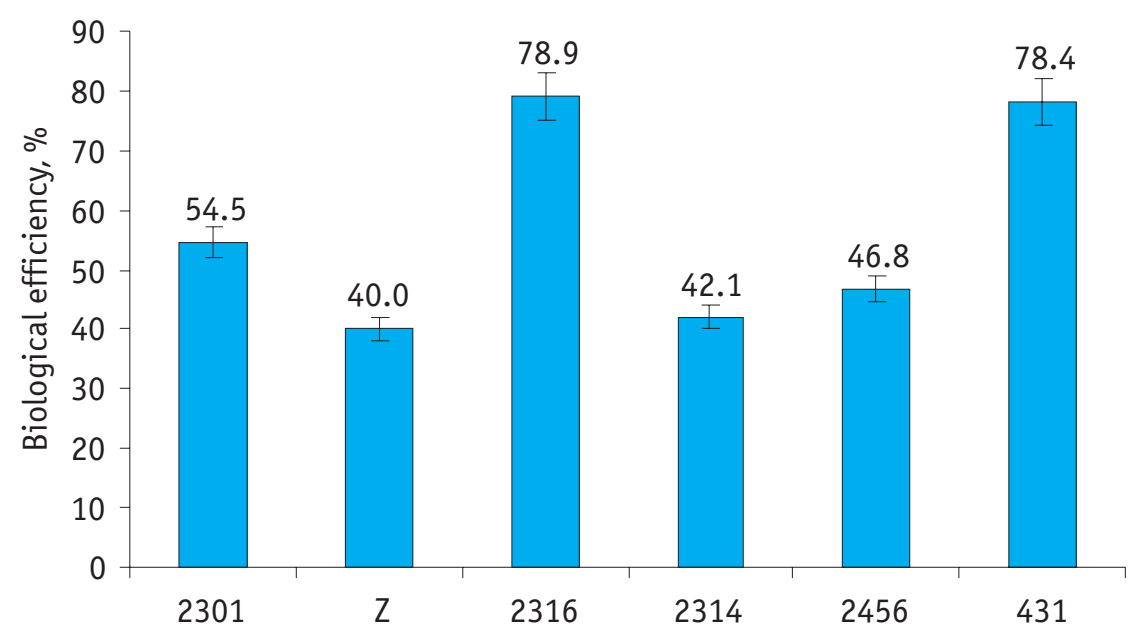

Fig. 1. Biological efficiency of strains after the first flush of fruiting (average for 2011-2019)

phological parameters of the clusters were determined (Table 2). The largest clusters were obtained in strain $431(430.7 \pm 27.5 \mathrm{~g})$, and the smallest - in strain $2314(83.4 \pm 6.7 \mathrm{~g})$. If in A group the strains did not differ in weight, then in B group all strains had a significant difference on this indicator.

In the experiment the maximum sizes were observed for the clusters of strain 431 (184.5 $\pm 3.8 \mathrm{~mm}$ in width and $172.8 \pm 4.1 \mathrm{~mm}$ in height), while the minimum sizes were in strain $2314(88.6 \pm 5.9$ and $63.6 \pm 4.0$, respectively). The asymmetry coefficient (AC) of the cluster characterizes its shape: rounded - when AC is close to one, extended - according to $\mathrm{AC}>1$, and elongated - if $\mathrm{AC}<1$. Strain 2314 had the highest asymmetry index in the experiment $(1.4 \pm 0.03)$. All strains tended to expand the cluster, but strains 2316 and 431 had the most rounded shape with the lowest asymmetry (1.04 \pm 0.04 and $1.09 \pm 0.02$, respectively). This indicator can be useful for calculating the required container sizes, which will prevent mechanical damage to the clusters during packing.

Interesting results were obtained when analyzing the number of fruiting bodies in the clusters. Such statistics influenced a significant decrease in the average indicator of the number of FBs in the cluster: $14.6 \pm 1.3(2301)$, $18.8 \pm 1.6(\mathrm{Z})$ and $19.6 \pm 1.5(2316)$, which is significantly lower in compared with strains 2314 and $431(36.7 \pm 2.2$ and $44.1 \pm 2.3$, respectively). The maximum number of FBs in clusters reached 127 (strain 431). The clusters of strain 2456 (B group) did not statistically differ from the strains of A group in the number of fruiting bodies, but were characterized by the lowest indicator of the maximum number of fruiting bodies in the clusters (52). Strain 2314 differed from others in the smallest size of FB, but had no tendency to form separate fruiting bodies in perforations (the smallest number of fruiting bodies in a cluster was 10).

The morphological characters of the fruiting bodies of the tested strains had significant differences in all the studied parameters (Table 3). In particular, the strains of A group differed in size and weight compared to strains of B group. The fruiting bodies of strains 2301 (56.5 \pm $1.8 \mathrm{~mm})$ and $\mathrm{Z}(54.3 \pm 1.9 \mathrm{~mm})$ had the largest width, the smallest - strains 2456 and 431 (33.4 \pm $0.9 \mathrm{~mm}$ and $33.6 \pm 1.3 \mathrm{~mm}$, respectively).

Characteristics of clusters (one-way analysis ANOVA), $\mathrm{p}<0.01$

Table 2

\begin{tabular}{|c|c|c|c|c|c|c|c|c|}
\hline \multirow{3}{*}{ Group } & \multirow{3}{*}{ Strain } & \multicolumn{7}{|c|}{ Index \pm Se (standard error) } \\
\hline & & \multirow{2}{*}{ Weight, g } & \multirow{2}{*}{ Width, mm } & \multirow{2}{*}{ Height, mm } & \multirow{2}{*}{$\begin{array}{l}\text { Asymmetry } \\
\text { coefficient }\end{array}$} & \multicolumn{3}{|c|}{ Number of fruiting bodies, pcs. } \\
\hline & & & & & & Mean & Min & Max \\
\hline \multirow{3}{*}{ A } & 2301 & $266.3^{b} \pm 23.1$ & $161.9^{b} \pm 4.3$ & $134.1^{\mathrm{b}} \pm 4.3^{2}$ & $1.26^{\mathrm{b}} \pm 0.03$ & $14.6^{\mathrm{b}} \pm 1.3$ & 1 & 66 \\
\hline & & $273.4^{b} \pm 24.0$ & $141.6^{b c} \pm 5.8$ & $110.5^{c} \pm 5.1$ & $1.33^{\mathrm{ab}} \pm 0.03$ & $18.8^{\mathrm{b}} \pm 1.6$ & 1 & 73 \\
\hline & 2316 & $220.8^{\mathrm{bc}} \pm 19.1$ & $121.7^{c} \pm 5.9$ & $128.3^{\mathrm{b}} \pm 8.4$ & $1.04^{c} \pm 0.04$ & $19.6^{\mathrm{b}} \pm 1.5$ & 2 & 58 \\
\hline \multirow{3}{*}{ B } & 2314 & $83.4^{\mathrm{d}} \pm 6.7$ & $88.6^{\mathrm{d}} \pm 5.9$ & $63.6^{\mathrm{d}} \pm 4.0$ & $1.40^{\mathrm{a}} \pm 0.03$ & $36.7^{a} \pm 2.2$ & 10 & 60 \\
\hline & 2456 & $188.0^{c} \pm 12.0$ & $169.4^{\mathrm{ab}} \pm 15.8$ & $139.4^{b} \pm 7.3$ & $1.28^{\mathrm{b}} \pm 0.09$ & $19.8^{\mathrm{b}} \pm 1.2$ & 1 & 52 \\
\hline & 431 & $430.7^{a} \pm 27.5$ & $184.5^{\mathrm{a}} \pm 3.8$ & $172.8^{\mathrm{a}} \pm 4.1$ & $1.09^{c} \pm 0.02$ & $44.1^{\mathrm{a}} \pm 2.3$ & 4 & 127 \\
\hline \multicolumn{2}{|c|}{$\mathrm{LCD}_{0.05}$} & 55.8 & 22.4 & 16.1 & 0.12 & 7.8 & - & - \\
\hline
\end{tabular}


Characteristics of fruiting bodies (one-way analysis ANOVA), $p<0.01$

\begin{tabular}{|c|c|c|c|c|c|c|c|c|c|c|}
\hline \multirow[b]{2}{*}{ Group } & \multirow[b]{2}{*}{ Strain } & \multicolumn{9}{|c|}{ Index \pm Se (standard error) } \\
\hline & & Width, mm & Height, mm & Area, $\mathrm{mm}^{2}$ & $\begin{array}{c}\text { Cap } \\
\text { asymmetry } \\
\text { coefficient }\end{array}$ & $\begin{array}{c}\text { FB weight, } \\
\mathrm{g}\end{array}$ & $\begin{array}{c}\text { Cap } \\
\text { weight, g }\end{array}$ & $\begin{array}{l}\text { Weight loss } \\
\text { coefficient }\end{array}$ & $\begin{array}{c}\text { Stipe } \\
\text { length, } \\
\text { mm }\end{array}$ & $\begin{array}{c}\text { Stipe } \\
\text { diameter, } \\
\mathrm{mm}\end{array}$ \\
\hline \multirow{3}{*}{ A } & 2301 & $56.5^{\mathrm{a}} \pm 1.8$ & $45.0^{\mathrm{a}} \pm 1.11$ & $2120^{\mathrm{a}} \pm 119$ & $1.25^{\mathrm{ab}} \pm 0.02$ & $15.2^{\mathrm{a}} \pm 1.0$ & $11.2^{\mathrm{a}} \pm 0.8$ & $0.72^{\mathrm{b}} \pm 0.01$ & $26.7^{b c} \pm 0.8$ & $20.5^{\mathrm{a}} \pm 0.6$ \\
\hline & & $54.3^{\mathrm{a}} \pm 1.9$ & $45.3^{\mathrm{a}} \pm 1.14$ & $2072^{\mathrm{a}} \pm 113$ & $1.19^{b} \pm 0.03$ & $14.1^{\mathrm{a}} \pm 0.8$ & $10.0^{\mathrm{a}} \pm 0.6$ & $0.71^{\mathrm{b}} \pm 0.01$ & $25.7^{c} \pm 1.1$ & $19.6^{\mathrm{a}} \pm 0.8$ \\
\hline & 2316 & $44.5^{\mathrm{b}} \pm 1.68$ & $44.6^{\mathrm{a}} \pm 1.15$ & $1677^{b} \pm 121$ & $0.99^{c} \pm 0.02$ & $11.1^{\mathrm{b}} \pm 0.9$ & $7.1^{\mathrm{b}} \pm 0.7$ & $0.62^{c} \pm 0.00$ & $34.4^{\mathrm{a}} \pm 1.1$ & $13.9^{\mathrm{b}} \pm 0.5$ \\
\hline \multirow{3}{*}{ B } & 2314 & $44.1^{b} \pm 1.5$ & $45.6^{\mathrm{a}} \pm 1.08$ & $1684^{b} \pm 95$ & $0.96^{c} \pm 0.02$ & $3.5^{c} \pm 0.2$ & $3.0^{c} \pm 0.2$ & $0.87^{\mathrm{a}} \pm 0.01$ & $18.6^{\mathrm{d}} \pm 0.8$ & $5.6^{\mathrm{d}} \pm 0.2$ \\
\hline & 2456 & $33.4^{c} \pm 0.9$ & $26.9^{c} \pm 0.62$ & $722^{\mathrm{d}} \pm 31$ & $1.28^{\mathrm{a}} \pm 0.04$ & $3.3^{c} \pm 0.2$ & $2.0^{\mathrm{d}} \pm 0.1$ & $0.59^{\mathrm{d}} \pm 0.01$ & $29.3^{\mathrm{b}} \pm 0.8$ & $15.2^{\mathrm{b}} \pm 0.6$ \\
\hline & 431 & $33.6^{c} \pm 1.3$ & $38.6^{\mathrm{b}} \pm 1.06$ & $1090^{c} \pm 69$ & $0.87^{\mathrm{d}} \pm 0.03$ & $5.1^{c} \pm 0.4$ & $3.8^{c} \pm 0.3$ & $0.72^{\mathrm{b}} \pm 0.01$ & $28.1^{\mathrm{bc}} \pm 1.9$ & $12.3^{c} \pm 0.7$ \\
\hline \multicolumn{2}{|c|}{$\mathrm{LCD}_{0.05}$} & 4.32 & 2.9 & 269 & 0.076 & 1.88 & 1.48 & 0.026 & 2.55 & 1.56 \\
\hline
\end{tabular}

The height index of the fruiting bodies was determined to check the asymmetry of the cap. The largest was found in strain 2314 (45.6 \pm $1.08 \mathrm{~mm})$, the smallest in strain $2456(26.9 \pm$ $0.62 \mathrm{~mm}$ ). But, in our opinion, better visualization of the size of the oyster mushroom cap can be achieved by comparing the cap area. In particular, strain 2301 had the largest cap area $\left(2120 \pm 119, \mathrm{~mm}^{2}\right)$, which was three times higher than that of strain $2456\left(722 \pm 31, \mathrm{~mm}^{2}\right)$ with the lowest result in the experiment. So, for the marketing policy of companies aimed at the European market, where consumers are used to buying oyster mushrooms only in the form of separate caps, it is better to pay attention to the strains of A group and strain 2314 of B group. For the manufacture of canned food, where it is better to use small fruiting bodies that look attractive in jars, strains 2456 and 431 are more suitable.

The coefficient of asymmetry of the cap characterizes the shape of the oyster mushroom cap; therefore, strain 2456 was the most extended shell-like shape $(\mathrm{AC}=1.28 \pm 0.04)$, while most of the caps of strain 431 were slightly leaf-like and elongated $(\mathrm{AC}=0.87 \pm$ 0.03). Fruiting bodies of strain 2316 had the most symmetrically rounded shape $(\mathrm{AC}=0.99$ \pm 0.02 ).

The mass of fruiting bodies of the strains of A group was significantly higher than that of B group: the largest mass of FB in the experiment was determined for strain 2301 (15.2 \pm $1.0 \mathrm{~g})$, the lowest for strain $2456(3.3 \pm 0.2 \mathrm{~g})$.

The yield weight loss factor makes it possible to predict the amount of mushroom raw material that will be sold at a high price as caps, and the amount of raw materials that can be processed into mushroom mince, powder and other valuable products. This approach improves the efficiency of the economy by expanding the range of products and scraps using. The best coefficient was obtained for fruiting bodies of strain $2314(0.87 \pm 0.01)$, and the worst for strain $2456(0.59 \pm 0.01)$, which, accordingly, we do not recommend for sale by separate fruiting bodies.

The strains differed in the length and diameter of the stipe. It is known that it is these indicators that are most dependent on the growing conditions, but taking into account the standard conditions in the growing chambers and the repetition of experiments, we can talk about the characteristics of the strain for this indicator, determined by the analysis results. In particular, the fruiting bodies of strain $2316(34.4 \pm 1.1 \mathrm{~mm})$ had the longest stipe in the experiment, while strain 2314 $(18.6 \pm 0.8 \mathrm{~mm})$ had the shortest one, which was also characterized by the smallest stipe diameter $(5.6 \pm 0.2 \mathrm{~mm})$. Strain 2301 had a thick stipe with a diameter of $20.5 \pm 0.6 \mathrm{~mm}$ (the best result in the experiment).

Unfortunately, the fruiting bodies of the highly productive strains 2316 and 431 had a number of organoleptic defects (Table 4, Fig. 2-8). Both strains had a firm stipe that did not change structure after blanching.

The «winter» strains 2301 and $\mathrm{Z}$ had a more intense coloration of the cap surface, dense «flesh» and a soft stipe (Figs. 2 and 3). The strains were characterized by large, dense clusters with a soft base.

The clusters of the fruiting bodies of the B group strains were looser, the basis of the cluster was firmer. It should be noted that strain 2314 ( $P$. pulmonarius) practically lacked the base of the cluster, which made it possible to separate the fruiting bodies during sorting without losing the mass of the mushroom raw material. In addition, the average size of the fruiting bodies of this strain was significantly lower, which plays an important role in the production of canned food. There is no need to cut them before placing them in a jar (Fig. 5 b).

The strains of B group («summer») had a brown cap color, therefore, despite the absence 
Table 4

Organoleptic evaluation of fruiting bodies of oyster mushroom strains

\begin{tabular}{|l|l|l|l|l|l|l|}
\hline \multirow{2}{*}{\multicolumn{1}{|c|}{ Criterion }} & \multicolumn{6}{c|}{ Strain } \\
\cline { 2 - 7 } & \multicolumn{1}{c|}{2301} & \multicolumn{1}{c|}{ Z } & \multicolumn{1}{c|}{2316} & \multicolumn{1}{c|}{2314} & \multicolumn{1}{c|}{2456} & \multicolumn{1}{c|}{431} \\
\hline Color & $\mathrm{d}$-gray & $\mathrm{d}$-gray & gray & l-brown & d-beige & d-beige \\
Texture & soft & soft & soft & firm & medium & firm \\
Aroma & weak & weak & weak & bright & weak & weak \\
Cap & thick & thick & medium & thin & thin & medium \\
Stipe diameter & large & large & medium & small & medium & medium \\
\hline
\end{tabular}

Note. Color: $d$ - dark; l - light.
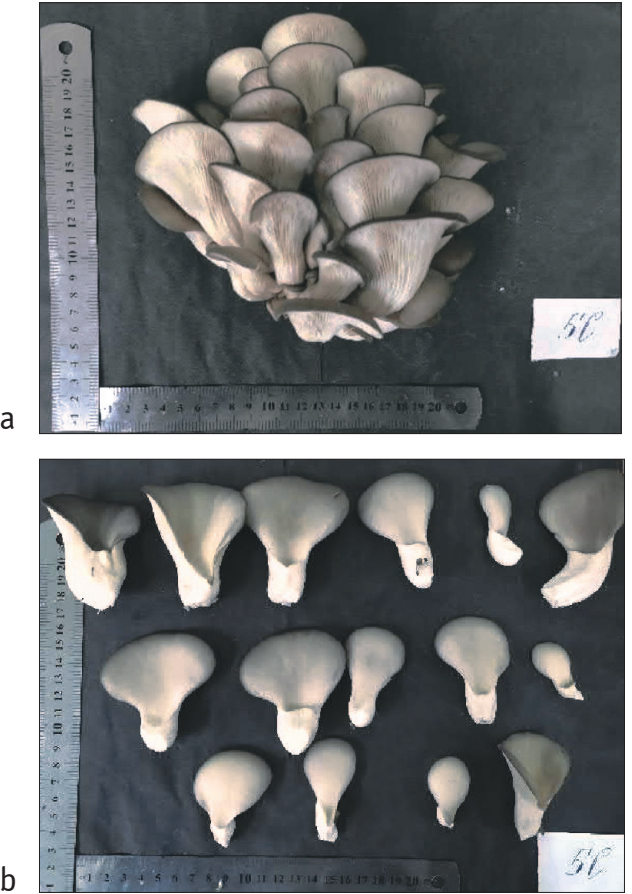

Fig. 2. Clusters (a) and fruiting bodies (b) of strain $2301(A)$
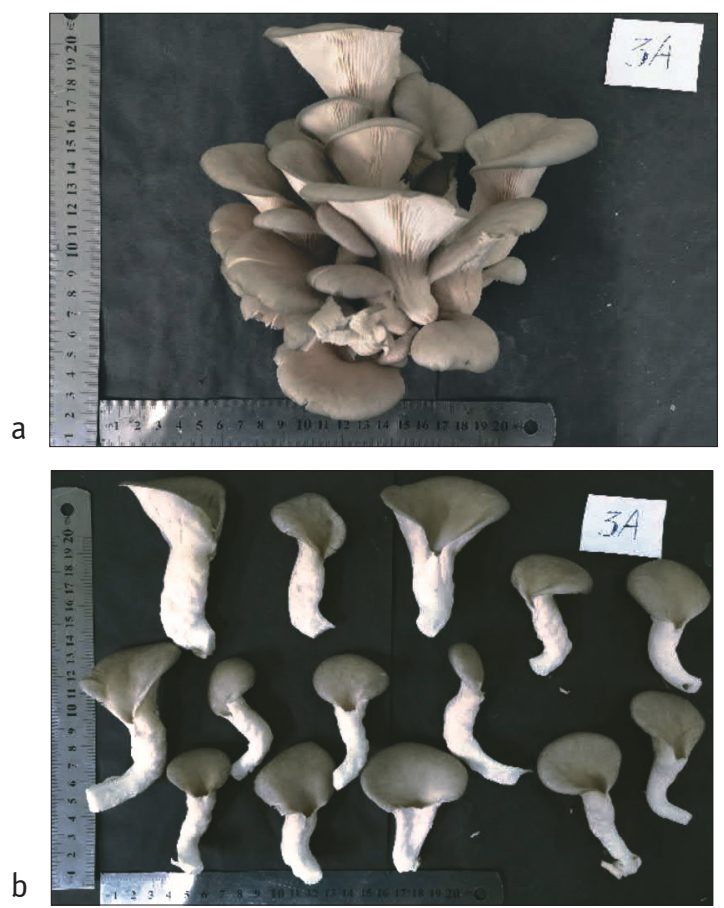

Fig. 4. Clusters (a) and fruiting bodies (b) of strain $2316(A)$
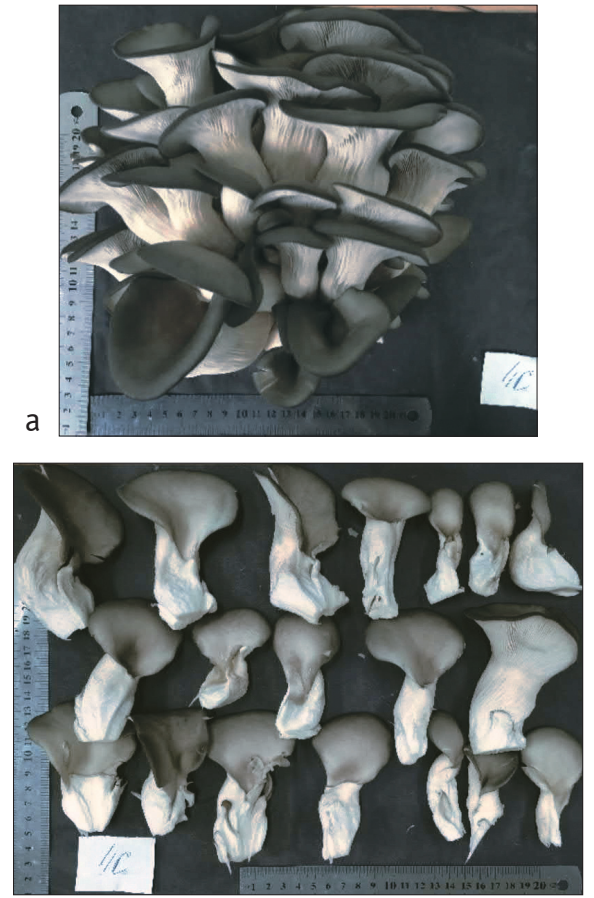

Fig. 3. Clusters (a) and fruiting bodies (b) of strain $Z(A)$

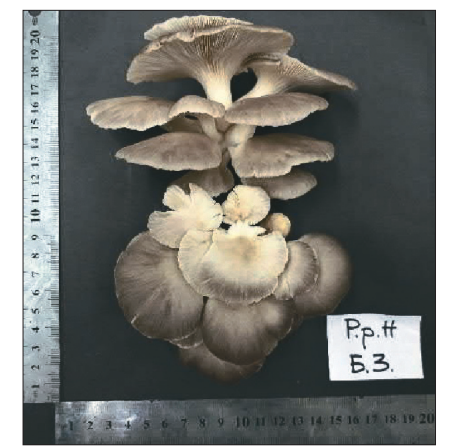

b

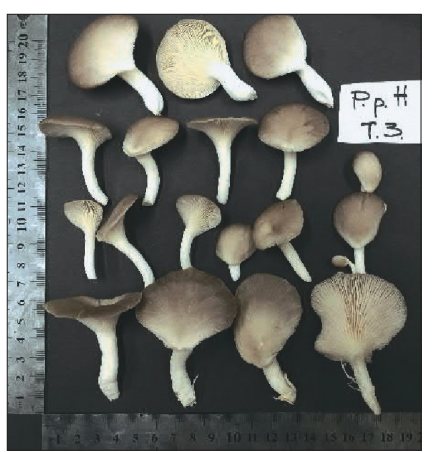

Fig. 5. Clusters (a) and fruiting bodies (b) of strain 2314 (C) 

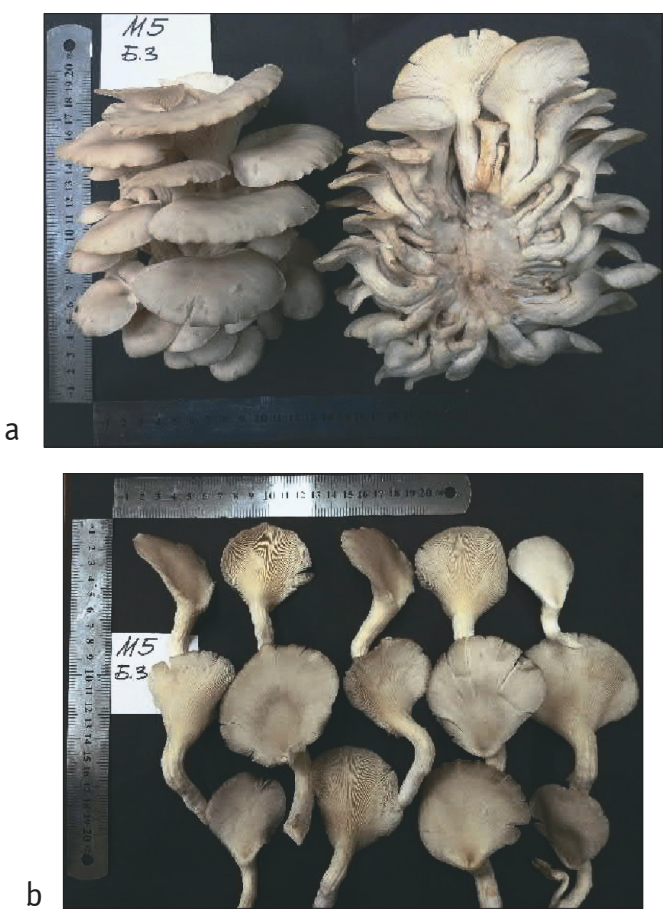

Fig. 6. Clusters (a) and fruiting bodies (b) of strain 2456 (B)
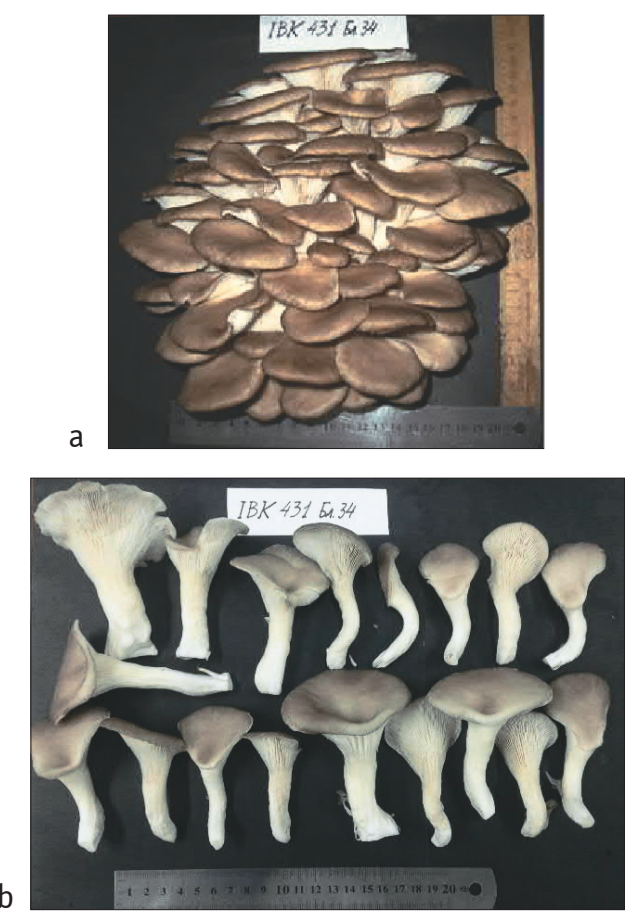

Fig. 7. Clusters (a) and fruiting bodies (b) of strain 431 (A) 6

of a definition of a «beige» shade in the «The method of DUS expert examination for vegetables, potatoes and mushrooms» [15], we were forced to use this term, since the definition of «light brown» was used to characterize the color of the FB of strain 2314, which integumentary tissues shade was some color tones darker.

\section{Conclusions}

Indicators of biological efficiency of six strains of oyster mushroom belonging to two species P. ostreatus (Fr.) P.Kumm (5 strains: $2301, \mathrm{Z}, 2316,2456,431$ ) and $P$. pulmonarius (Fr.) Quйl (2314), cultivated in Ukraine since 2011 were determined. The highest average values for the first flush of fruiting had strains $2316(78.9 \%)$ from the "winter» group (A) and $431(78.4 \%)$ from the «summer» group (B). The studied groups of strains did not have significant differences in biological effectiveness, which allows us to speak about the expediency of «summer» cultivation. The change of strains makes it possible to get a harvest throughout the year without additional economic costs for cooling or heating the cultivation premises.

According to the results of statistical analysis, significant differences were established between the studied strains in terms of the main morphological parameters of the clusters (weight, width, height, asymmetry coefficient, the number of fruiting bodies in the cluster). It was revealed that the mass of clusters of the investigated "winter» cultivars depends much less on belonging to the strain type (220.8$273.4 \mathrm{~g})$ than that of the "summer» cultivars (83.4-430.7 g). An indicator, the coefficient of asymmetry of the cluster is proposed, which can be useful for calculating the required container sizes to prevent mechanical damage to products during packing and transportation.

It was revealed that the morphological features of the fruiting bodies of the tested strains had significant differences in all studied parameters: width, height, area, cap asymmetry coefficient, fruiting body weight, cap weight, weight loss coefficient, stipe length, stipe diameter. In particular, the strains of A group differed in their larger size and mass, compared with strains of B group. The greatest mass of FB was determined for strain $2301(15.2 \pm 1.0 \mathrm{~g})$, the smallest for $2456(3.3 \pm 0.2 \mathrm{~g})$. The proposed indicator is the coefficient of loss of weight of the crop, which shows the ratio between the cap and the stipe of the FB and makes it possible to predict the amount of mushroom raw materials that will be sold at a high price as caps, and the amount of raw material that can be processed into mushroom mince, powder and other valuable products. The best coefficient was obtained for fruiting bodies of strain $2314(0.87 \pm 0.01)$, the worst for strain $2456(0.59 \pm 0.01)$, which we do not recommend for sale by separate fruiting bodies. It was found that the fruiting bodies of high-performance strains 2316 and 431 had a number of organoleptic defects. 


\section{References}

1. Royse, D. J. (2014). A global perspective on the high five: Agaricus, Pleurotus, Lentinula, Auricularia \& Flammulina. In Proceedings of $8^{\text {th }}$ International Conference on Mushroom Biology and Mushroom Products (Vol. I \& II, pp. 1-6). Nov. 19-22, 2014, New Delhi, India.

2. Lucier, G., Allshouse, J., \& Lin, B.-H. (2003). Factors Affecting U.S. Mushroom Consumption. Economic Research Publication VGS 29501. Retrieved from http://guerillagreen.wagn.org/files/Factors_affecting_US_mushroom_consumption-2123.pdf

3. Zhang, Y., Geng, W., Shen, Y., Wang, Y., \& Dai, Y.-C. (2014). Edible Mushroom Cultivation for Food Security and Rural Development in China: Bio-Innovation, Technological Dissemination and Marketing. Sustainability, 6(5), 2961-2973. doi: 10.3390/ su6052961

4. Bandura, I. I., Mironycheva, E. S., \& Kyurcheva, L. N. (2014). Selection of the Pleurotus pulmonarius (Fr.) Quél strains which are resistant to high temperatures of cultivation. Ştiința agricolă, 2, 56-59. [in Russian]

5. Bandura, I. I., \& Mironycheva, E. S. (2013). Biological efficiency of the Pleurotus ostreatus (Jacq: Fr) Kumm strains at the low-temperature cultivation. Zemledelie i zashhita rastenij [Agriculture and Plant Protection], 5, 33-35. [in Russian]

6. Bis'ko, N. A., \& Dudka, I. A. (1987). Biologiya i kul'tivirovanie sedobnykh gribov roda veshenka [Biology and cultivation of edible oyster mushrooms]. Kyiv: Naukova dumka. [in Russian]

7. Holub, H. A., Abrosimova, H. L., Haidenko, 0. M., Kepko, 0. I., \& Tomashchuk, A. I. (2010). Tekhnolohichnyi protses vyrobnytstva substratu dlia vyroshchuvannia hlyvy metodom fermentatsii $v$ pasteryzatsiinii kameri [Technological process of the production of the substrate for cultivation fungus using pasteurization chamber fermentation method]. Kyiv: Naukovyi svit. [in Ukrainian]

8. Pochinok, H. N. (1976). Metody biohimicheskogo analiza rasteniy [Methods of biochemical analysis of plants]. Kyiv: Naukova dumka. [in Russian]

9. Dudka, I. A. (1978). Promyshlennoe kul'tivirovanie sedobnykh gribov [Industrial cultivation of the edible mushrooms]. Kyiv: Naukova dumka. [in Russian]

10. Mitselii yistivnykh hrybiv substratnyi. Tekhnichni umovy: DSTU 7316:2013 [Substrate mycelium of the edible mushrooms. Technical conditions: National standard of Ukraine 7316:2013]. (2010). Kyiv: Minekonomrozvytku Ukrainy. [in Ukrainian]

11. Tarariko, 0. G., Baljuk, S. A., \& Kisil, V. I. (2005). Metodyka ahrokhimichnoho obstezhennia teplychnykh gruntiv i substrativ ta osoblyvosti zastosuvannia dobryv [Methods of agrochemical examination of greenhouse soils and substrates and features of fertilizer application]. Kyiv: DIA. [in Ukrainian]

12. Hoa, H. T., Wang, C.-L., \& Wang, C.-H. (2015). The Effects of Different Substrates on the Growth, Yield, and Nutritional Composition of Two Oyster Mushrooms (Pleurotus ostreatus and Pleurotus cystidiosus). Mycobiology, 43(4), 423-434. doi: 10.5941/ MYC0.2015.43.4.423

13. Vdovenko, S. A., \& Siwulski, M. (2013). The quality of fruiting bodies of oyster mushroom when grown in protected soil. Rosl. gruntozn. [Plant and Soil Science], 183(1), 82-90. [in Ukrainian]

14. Vdovenko, S. A. (2013). Yield formation of Oyster mushroom under the intensive method of growing. Visnik PDAA [Bulletin of Poltava State Agrarian Academy], 4, 26-29. doi: 10.31210/ visnyk2013.04.06 [in Ukrainian]

15. The method of oyster mushrooms strains (Pleurotus ostreatus (Jacq.) P.Kumm., Pleurotus eryngii (DC.) Quél., Pleurotus pulmonarius (Fr.) Quél.) examination on Distinctne ss, Uniformity and Stability. (2016). In S. 0. Tkachyk (Ed.), Metodyka provedennia ekspertyzy sortiv roslyn hrupy ovochevykh, kartopli ta hrybiv na vidminnist, odnoridnist $i$ stabilnist [The method of DUS expert examination for vegetables, potatoes and mushrooms] (pp. 1075-1086). (2 ${ }^{\text {nd }}$ ed., rev.). Vinnytsia: Nilan-LTD. [in Ukrainian]

\section{Використана література}

1. Royse D. J. A global perspective on the high five: Agaricus, Pleurotus, Lentinula, Auricularia \& Flammulina. Proceedings of 8th International Conference on Mushroom Biology and Mushroom Products (New Delhi, India, November 19-22, 2014). New Delhi, 2014. Vol. I \& II. 2014. P. 1-6.

2. Lucier G., Allshouse J., Lin B-H. Factors Affecting U.S. Mushroom Consumption. Economic Research Publication VGS 295-01. (March 2003). URL: http://guerillagreen.wagn.org/files/ Factors_affecting_US_mushroom_consumption-2123.pdf

3. Zhang Y., Geng W., Shen Y. et al. Edible Mushroom Cultivation for Food Security and Rural Development in China: BioInnovation, Technological Dissemination and Marketing. Sustainability. 2014. Vol. 6, Iss. 5. P. 2961-2973. doi: 10.3390/ su6052961

4. Бандура И. И., Миронычева Е. С., Кюрчева Л. Н. Отбор устойчивых к высоким температурам культивирования штаммов Pleurotus pulmonarius (Fr.) Quél. Ştiința agricolă. 2014. Nr. 2. P. 56-59.

5. Бандура И. И., Миронычева Е. С. Биологическая эффективность штаммов вешенки обыкновенной Pleurotus ostreatus (Jacq: Fr) Kumm при низкотемпературном культивировании. Земледелие и защита растений. 2013. Вып. 5. С. 33-35.

6. Бисько Н. А.,Дудка И. А. Биология и культивированиесъедобных грибов рода вешенка. Киев : Наук. думка, 1987. 148 с.

7. Голуб Г. А., Абросімова Г. Л., Гайденко 0. М. та ін. Технологічний процес виробництва субстрату для вирощування гливи методом ферментації в пастеризаційній камері. Київ : Наук. Світ, 2010. 30 с.

8. Починок Х. Н. Методы биохимического анализа растений. Киев : Наук. думка, 1976. 336 с.

9. Дудка И. О. Промышленное культивирование съедобных грибов. Киев : Наук. думка, 1978. 262 с.

10. Міцелій їстівних грибів субстратний. Технічні умови : Дсту 7316:2013. [Чинний від 2014-01-01]. Київ : Мінекономрозвитку України, 2014. 10 с.

11. Методика агрохімічного обстеження тепличних ґрунтів і субстратів та особливості застосування добрив / за ред. Д. М. Бенцаровського, С. І. Мельника, О. Г. Тараріко. Київ : ДІА, 2005. 208 c.

12. Hoa H. T., Wang C.-L., Wang C.-H. The Effects of Different Substrates on the Growth, Yield, and Nutritional Composition of Two Oyster Mushrooms (Pleurotus ostreatus and Pleurotus cystidiosus). Mycobiology. 2015. Vol. 43, Iss. 4. P. 423-434. doi: 10.5941/MYC0.2015.43.4.423

13. Вдовенко С. А. Сівульский М. Якість плодових тіл гливи звичайної за вирощування в захищеному ґрунті. Рослинництво та ґрунтознавство. 2013. Вип. 183(1). С. 82-90.

14. Вдовенко С. А. Формування врожаю гливи звичайної за інтенсивного вирощування. Вісник ПДАА. 2013. № 4. С. 26-29. doi: 10.31210/visnyk2013.04.06

15. Методика проведення експертизи штамів гливи (Pleurotus ostreatus (Jacq.) P.Kumm., Pleurotus eryngii (DC.) Quél., Pleurotus pulmonarius (Fr.) Quél.) на відмінність, однорідність і стабільність. Методика проведення експертизи сортів рослин групи овочевих, картоплі та грибів на відмінність, однорідність і стабільність / за ред. С. 0. Ткачик. 2-ге вид., випр. і доп. Вінниця : Нілан-ЛТД, 2016. С. 1075-1086. 


\section{удК 631.5:635.89}

Бандура I. I. ${ }^{*}$, Кулик А. С. ${ }^{1}$, Бісько Н. А. ${ }^{2}$, Хареба О. В. ${ }^{3}$, Цизь 0. М. ${ }^{4}$, Хареба В. В. ${ }^{3}$ Аналіз біологічної ефективності та чинників якості грибів роду глива (Pleurotus (Fr.) P.Kumm) як моделі ефективного культивування ксилотрофів з високою функціональною цінністю. Plant Varieties Studying and Protection. Т. 16, № 4. C. 334-342. https://doi.org/10.21498/2518-1017.16.4.2020.224047

${ }^{1}$ Таврійський державний агротехнологічний університет ім. Д. Моторного, пр-m Б. Хмельницького, 18, м. Мелітополь, Запорізька обл., 72312, Україна, ”e-mail: irabandura@gmail.com

${ }^{2}$ Iнститут ботаніки ім. М. Г. Холодного НАН України, вул. Терещенківська, 2, м. Київ, 01004, Україна

${ }^{3}$ Національна академія аграрних наук України, вул. М. Омельяновича-Павленка, 9, м. Київ, 01010, Україна

${ }^{4}$ Національний університет біоресурсів і природокористування України, вул. Героїв Оборони, 15, м. Київ, 03041, Україна

Мета. Провести морфологічну та органолептичну оцінку штамів гливи для добору асортименту високопродуктивних і цінних за споживчими властивостями культиварів для зимового й літнього культивування та придатності до реалізації у свіжому або переробленому вигляді. Методи. Схема досліду включає 6 штамів гливи, що належать до двох видів: Pleurotus ostreatus (5 штамів: 2301, Z, 2316, 2456, 431) i Pleurotus pulmonarius (2314). Використано лабораторний, лабораторно-виробничий та статистичний методи досліджень. Результати. Динаміка агрохімічних показників субстратів, отриманих методом аеробної ферментації у високому шарі, засвідчила їхню оптимальність за основними критеріями та відповідність нормативній документації. Біологічна ефективність штамів знаходилася в інтервалі 40-78,9\%. Найбільшу масу зростків установлено в «літнього» штаму 431 (430,7 г). Найбільшу масу плодового тіла визначено для штаму 2301 (15,2 г), найменшу - для 2456 (3,3 г). Висновки. Визначено показники біологічної ефективності штамів. Найвищі середні значення за першою хвилею плодоношення мали штами 2316 (78,9\%) із групи «зимових» (A) і $431(78,4 \%)$ із групи «літніх» (B). За результатами статистичного аналізу встановлено суттєві відмінності між досліджуваними штамами за основними морфологічними показниками зростків. Виявлено, що маса зростків «зимових» культиварів значно менше залежить від штамової приналежності (220,8-273,4 г), ніж «літніх» (83,4-430,7 г). Запропоновано показник коефіцієнт асиметрії зростка, який може бути корисним для розрахунку необхідних розмірів тари. Виявлено, що морфологічні ознаки плодових тіл мали суттєві відмінності за всіма дослідженими параметрами. Зокрема, штами групи А відрізнялися більшими розмірами й масою. Запропоновано показник - коефіцієнт утрати маси врожаю, який показує співвідношення між шапинкою й ніжкою плодового тіла та дає змогу спрогнозувати кількість грибної сировини, яку буде реалізовано у вигляді шапинок, та кількість сировини, яку можна переробити у грибний фарш, порошок та ін. Найкращий коефіцієнт отримано для плодових тіл штаму $2314(0,87)$, а найгірший - $2456(0,59)$, який, відповідно, не рекомендуємо до реалізації окремими плодовими тілами. Установлено, що плодові тіла високопродуктивних штамів 2316 і 431 мали низку органолептичних недоліків.

Ключові слова: глива; штами; біологічна ефективність; зросток; плодове тіло; органолептична оцінка.

Надійшла / Received 11.11.2020 Погоджено до друку / Accepted 30.11.2020 